\title{
RANCANG BANGUN NEW NORMAL COVID-19 MASKER DETEKTOR DENGAN NOTIFIKASI TELEGRAM BERBASIS INTERNET OF THINGS
}

\author{
Musakkarul Mu'minim Lambacing', Ferdiansyah'² \\ ${ }^{1,2}$ Program Studi Teknik Informatika, Fakultas Teknologi Informasi, Universitas Budi Luhur \\ e-mail: ${ }^{1}$ Musakkarul.lambatjing@gmail.com, ${ }^{2}$ Ferdiansyah@budiluhur.ac.id
}

\begin{abstract}
Abstrak
Dimasa pandemi COVID-19 saat ini diberlakukanlah peraturan di mana setiap orang wajib menggunakan masker dan melakukan physical distancing pada saat keluar rumah di Jakarta. Ini merupakan salah satu kebiasaan baru yang akan dibiasakan ke masyarakat oleh pemerintah. Pada lingkungan perusahaan yang sudah mulai beroperasi $50 \%$, juga mewajibkan karyawannya menggunakan masker dan physical distancing saat di kantor. Agar kebiasaan disiplin menggunakan masker di tempat umum ini dapat berjalan dengan baik, maka dibuatlah New Normal COVID-19 Masker Detektor dengan Notifikasi Telegram berbasis Internet Of Things ini agar lingkungan seperti perusahaan dapat mendisiplinkan karyawannya untuk menggunakan masker sebelum masuk ke kantor. Sistem ini dibuat menggunakan Raspberry Pi sebagai otak utamanya, dengan menambahkan modul kamera dan juga sensor PIR, yang akan mendeteksi apakah orang tersebut menggunakan masker atau tidak. Kemudian akan dikirimkan pesan notifikasi telegram kepada keamanan setempat agar orang tersebut diperbolehkan masuk ke kantor jika sudah menggunakan masker. Metode penelitian yang dilakukan adalah dengan merumuskan masalah yang ada,kemudian merumuskan tujuan penelitian, melakukan studi literatur, melakukan perancangan sistem dan melakukan pengujian sistem. Hasil dari penelitian ini adalah sistem dapat mendeteksi orang yang menggunakan masker dan notifikasi dapat dikirimkan ke keamanan melalui aplikasi telegram dengan baik.
\end{abstract}

Kata Kunci: COVID-19, Raspberry Pi, Masker, Object Detection, Telegram

\section{PENDAHULUAN}

COVID-19 melanda Indonesia sejak Maret 2020 hingga saat tulisan ini dibuat. Pemerintah selaku pembuat kebijakan, memberlakukan peraturan baru agar setiap orang dapat keluar rumah dan melakukan pekerjaan tanpa harus khawatir terpapar virus COVID-19 ini. Salah satunya adalah peraturan yang dibuat oleh Gubernur DKI Jakarta yaitu bagi setiap orang yang akan keluar rumah wajib menggunakan masker dan juga tetap melakukan physical distancing[1]. Kondisi tersebut juga berlaku untuk para pekerja di kantornya masing-masing. Di mana setiap karyawan wajib menggunakan masker saat bekerja dan juga melakukan physical distancing guna menghindari penyebaran virus COVID-19 ini. Penularan virus COVID-19 ini sendiri dapat terjadi melalui percikan saat bersin atau batuk antar manusia[2]. Oleh karena itu penggunaan masker menjadi sangat penting untuk melakukan kegiatan seharihari saat keluar rumah.

Dari isu tersebut dibuatlah penelitian dengan memanfaatkan Teknologi Informasi dengan membuat New Normal COVID-19 Masker Detektor dengan Notifikasi Telegram berbasis Internet Of Things ini. Dengan memanfaatkan mini komputer seperti Raspberry Pi yang merupakan sebuah mini komputer seukuran kartu kredit yang mempunyai cukup spesifikasi untuk melakukan banyak hal[3],[4]. Sistem pada chip (SoC) Raspberry Pi memiliki kemampuan untuk membaca sensor-sensor yang dihubungkan pada pinnya. Sehingga dapat digabungkan dengan bermacam-macam sensor elektronik, seperti sensor suhu, sensor gerak, sensor pir, sensor kamera, dan lainnya. Kelebihan utama Raspberry Pi adalah dapat melakukan segala hal yang dapat dilakukan oleh komputer/laptop seperti mengedit dokumen, memutar 
video HD, bermain game, coding, dengan sistem operasi Linux[3]. Selain itu Raspberry Pi juga dapat membuat program dengan berbagai macam bahasa, terutama bahasa tingkat tinggi seperti Python.

Metode yang digunakan adalah dengan menggunakan Deep Learning Convolutional Neural Network untuk mengklasifikasikan data yang sudah di label dengan menggunakan metode supervised learning. Di mana cara kerjanya adalah dengan melatih data yang memiliki variabel sendiri untuk ditargetkan dan kemudian nantinya akan dikelompokkan berdasarkan variabel data tersebut. Metode ini sering digunakan untuk mengenali benda, pemandangan dan melakukan deteksi juga segmentasi objek[5],[6]. Pada penelitian ini data yang digunakan adalah data dari orang yang menggunakan masker dan tidak menggunakan masker.

Model yang sudah dilatih kemudian akan dijalankan oleh Raspberry Pi, untuk kemudian akan mendeteksi apakah orang menggunakan masker atau tidak. Jika orang tersebut menggunakan masker, maka akan dikirimkan notifikasi melalui telegram ke keamanan setempat agar orang tersebut dapat diberikan akses masuk ke dalam kantor.

\section{TINJAUAN PUSTAKA}

\subsection{Penelitian Smart Motion Detection Menggunakan Raspberry Pi dan PIR sensor}

Pada penelitian ini Venkat Margapuri melakukan penelitian dengan menggunakan Raspberry Pi dan PIR Sensor juga Kamera untuk keperluan keamanan di dalam rumah. Dalam penelitiannya dibahas bahwa PIR Sensor memiliki 2 bagian, di mana setiap bagiannya memiliki sensitivitas terhadap sinar infra merah dan juga lensa. Kedua bagian tersebut dapat mendeteksi pergerakan manusia dengan jarak tertentu tergantung dengan sensitivitas dan jaraknya[7]. Cara kerja dari PIR Sensor sendiri ditunjukkan pada gambar 1.

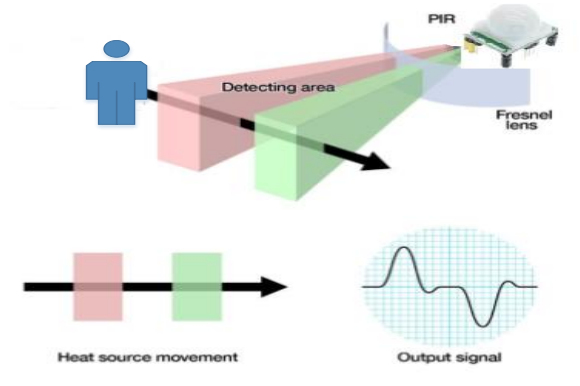

Gambar 1. Cara Kerja PIR Sensor

\subsection{Penelitian RetinaMask Detection}

Pada penelitian ini Mingjie Jiang, Xinqi Fan, dan Hong Yan, membuat sistem bernama Retina Face Mask, sebuah masker detector dengan menggunakan ResNet dan MobileNet sebagai algoritma utama untuk melakukan Deep Learningnya[8]. Di mana setiap gambar yang dilatih memiliki perbandingan masing-masing dari hasilnya, seperti ditunjukan pada Tabel 1.

Tabel 1. Perbandingan Presisi deteksi Masker

\begin{tabular}{|c|c|c|c|c|c|}
\hline \multirow{2}{*}{ Backbone } & \multirow{2}{*}{ Transfer Learning } & \multicolumn{2}{|c|}{ Face } & \multicolumn{2}{c|}{ Mask } \\
\cline { 3 - 6 } & & Precision & Recall & Precision & Recall \\
\hline \multirow{3}{*}{ MobileNet } & \multirow{2}{*}{ Imagenet } & $80.5 \%$ & $93.0 \%$ & $82.8 \%$ & $89.0 \%$ \\
\cline { 3 - 6 } & \multirow{2}{*}{ Wilder Face } & $79.0 \%$ & $92.8 \%$ & $78.9 \%$ & $89.1 \%$ \\
\cline { 3 - 6 } & & $83.0 \%$ & $95.6 \%$ & $82.3 \%$ & $89.1 \%$ \\
\hline \multirow{3}{*}{ ResNet } & \multirow{2}{*}{ Imagenet } & $91.0 \%$ & $95.4 \%$ & $82.4 \%$ & $89.3 \%$ \\
\cline { 3 - 6 } & \multirow{2}{*}{ Wilder Face } & $91.5 \%$ & $95.6 \%$ & $93.2 \%$ & $94.4 \%$ \\
\cline { 3 - 6 } & & $91.9 \%$ & $96.3 \%$ & $93.3 \%$ & $94.4 \%$ \\
\cline { 3 - 6 } & & $95.7 \%$ & $92.9 \%$ & $94.8 \%$ \\
\hline
\end{tabular}


Dari hasil di atas menunjukkan ResNet memiliki tingkat akurasi yang lebih baik ketimbang MobileNet. Namun kekurangannya adalah ResNet membutuhkan sumber daya yang cukup besar terutama kartu grafis dari PC untuk melakukan pelatihan terhadap data yang ada.[9]

\subsection{Raspberry Pi Sebagai Processor Pada Pendeteksian Dan Pengenalan Pola Wajah}

Pada penilitian ini Fadli Sirait dan Yoserizal menggunakan Raspberry Pi sebagai otaku tama dala sistem pendeteksian dan pengenalan citra wajah. Raspberry Pi yang digunakan adalah tipe Raspberry Pi 3 B+ seperti yang ditunjukkan pada gambar 2.

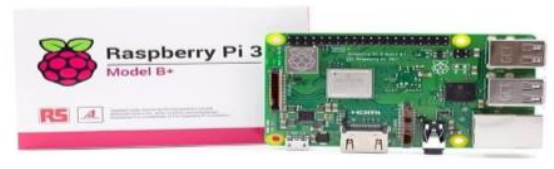

Gambar 2. Raspberry Pi 3 B+

Perancangan sistem yang dibuat menggunakan metode pengenalan citra wajah dengan Haar Cascade Classifier yang diimplementasikan pada library OpenCV, sedangkan metode pengenalan pola wajah menggunakan metode PCA(Principal Component Analysist) dan LDA(Linear Discriminant Analysist).[10]

\section{METODE PENELITIAN}

Metode penelitian yang dilakukan untuk membangun sistem New Normal COVID-19 Masker Detektor dengan notifikasi Telegram berbasis Internet Of Things ini meliputi, merumuskan masalah, merumuskan tujuan penelitian, studi literatur, merancang sistem, dan pengujian sistem.

\subsection{Merumuskan Masalah}

Pada tahapan ini dilakukan perumusan masalah yang terjadi di lapangan. Pada masa pandemi seperti sekarang adalah kebiasaan masyarakat yang harus diubah, di mana setiap orang harus menggunakan masker dan melakukan physical distancing untuk dapat menekan penyebaran virus COVID-19 ini. Terutama ketika masuk ke dalam lingkungan kantor di mana terkadang orang lupa untuk menjaga jarak ataupun menggunakan masker ketika bekerja.

\subsection{Merumuskan Tujuan Penelitian}

Setelah kita mengetahui masalah yang ada, tujuan penelitian mulai dirumuskan. Yaitu, agar setiap orang dapat melaksanakan peraturan yang berlaku dan juga menjaga dirinya sendiri dengan menggunakan masker saat akan bekerja, juga tetap menjaga jarak saat di lingkungan pekerjaan.

\subsection{Studi Literatur}

Studi literatur dilakukan untuk menganalisa dan mencari sistem yang tepat untuk di aplikasikan, dan dapat memenuhi tujuan penelitian juga menyelesaikan masalah yang ada.

\subsection{Perancangan Sistem}

Pada tahapan ini dilakukan perancangan sistem New Normal COVID-19 Masker Detektor dengan notifikasi Telegram berbasis Internet OfThings. Dengan Raspberry Pi sebagai otak utamanya yang sudah di install Tensorflow dan Keras sebagai Deep Learning Computer Visionnya, dan juga menggunakan modul kamera juga PIR sensor sebagai deteksi orang dan maskernya. Kemudian notifikasinya akan dikirim menggunakan aplikasi Telegram kepada petugas keamanan yang berjaga. topologi dan flow chart dari rancangan sistem ini ditunjukkan pada Gambar 3 dan Gambar 4. 


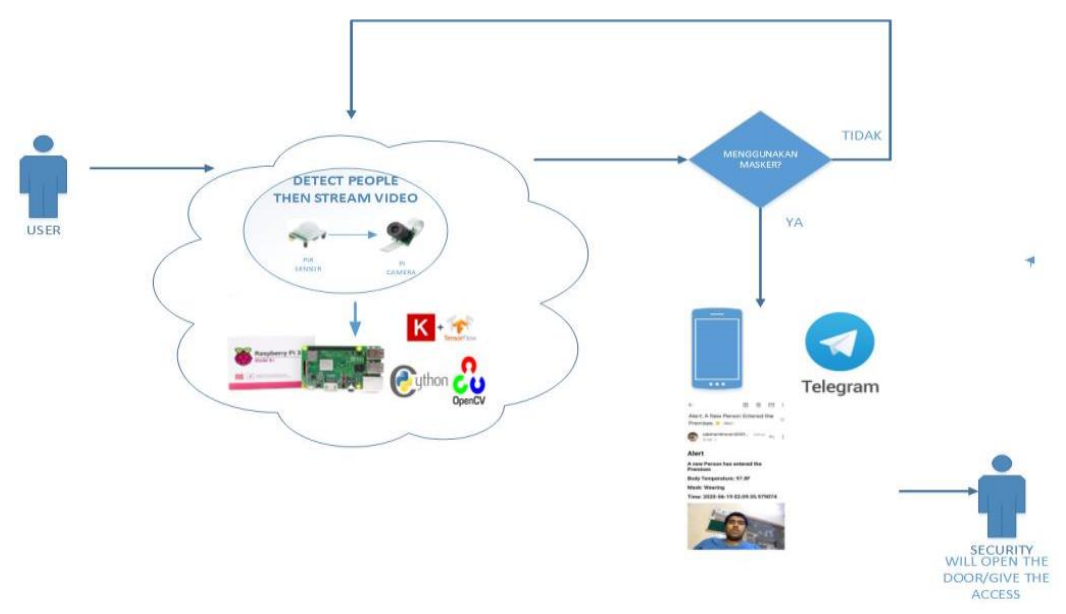

Gambar 3. Topologi System

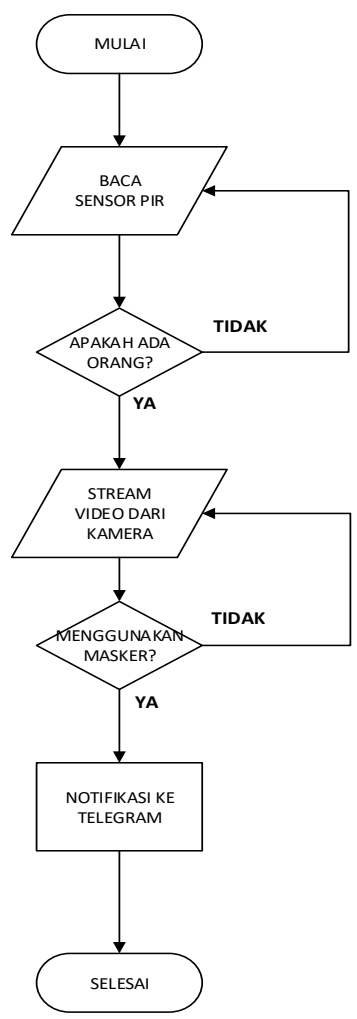

Gambar 4. Flow Chart Sistem

\subsection{Pengujian Sistem}

Pada tahapan ini dilakukan pengujian sistem dengan metode black-box, di mana semua fungsi diuji apakah semua sistem dapat berjalan dengan lancar dari mulai pendeteksian maskernya sampai dengan notifikasi Telegram yang akan di terima.

\section{HASIL DAN PEMBAHASAN}

Dalam penelitian Rancang Bangun New Normal Masker COVID-19 Detektor dengan Notifikasi Telegram berbasis Internet Of Things ini menggunakan sekelompok Data yang kemudian dibagi menjadi 2 variabel, yaitu with masker sebanyak 1915 gambar, dan without masker sebanyak 1918 gambar. Kumpulan dataset tersebut ditunjukkan pada Gambar 5. 


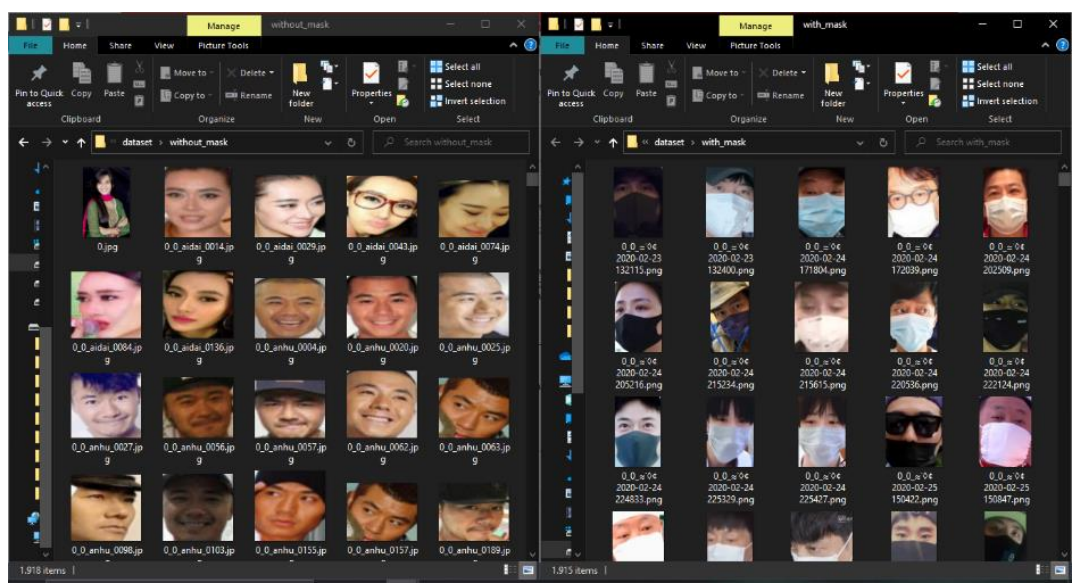

Gambar 5. Kumpulan Dataset

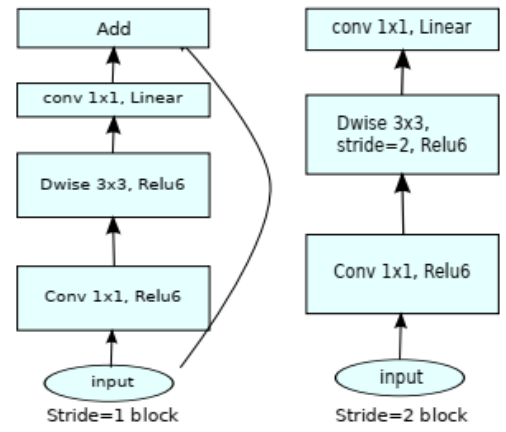

Gambar 6. Blok Arsitektur MobileNetV2

Dataset tersebut dilakukan pelatihan dengan Deep Learning menggunakan algoritma MobileNetV2 yang merupakan versi terbaru dari MobileNet dalam arsitektur CNN(Convolutional Neural Network) di mana memiliki memory yang kecil sehingga dapat di aplikasikan dalam Raspberry Pi.[11] MobileNet membagi convolution menjadi depthwise convolution dan pointwise convolution[12] seperti ditunjukan pada gambar 6.

Proses latih data membutuhkan waktu yang cukup lama, tergantung dari seberapa baiknya perangkat yang digunakan untuk proses latihan data ini. Tampilan proses saat pelatihan ditunjukkan pada Gambar 7.

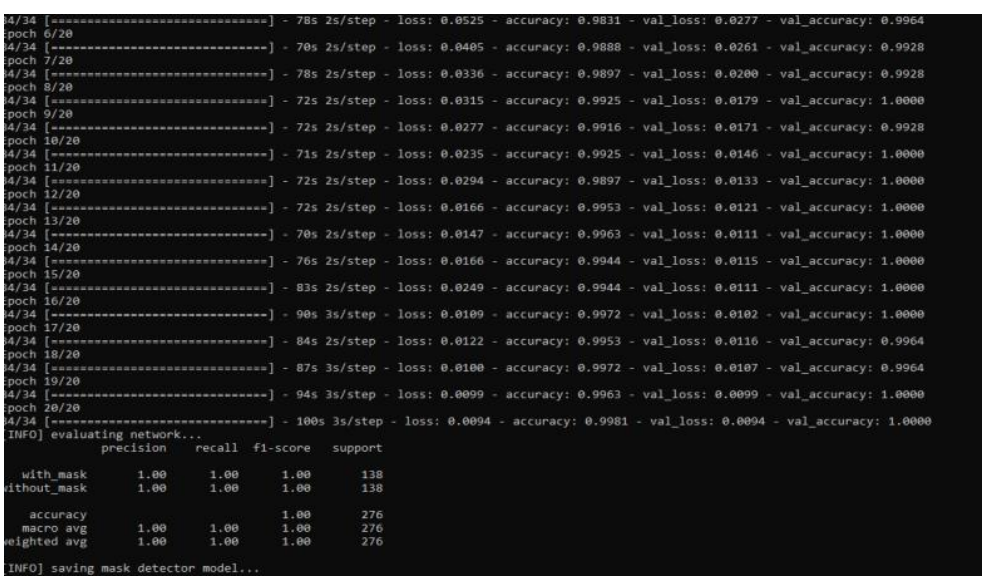

Gambar 7. Training Dataset

Dari proses latih tersebut menunjukkan akurasi yang cukup tinggi dalam mendeteksi masker COVID-19 dengan dataset yang ada, dari hasil tersebut kita bisa mengaplikasikan model yang sudah ada tersebut ke dalam Raspberry Pi. Grafik dari hasil proses latih dataset masker detektor ditunjukkan pada gambar 8. 


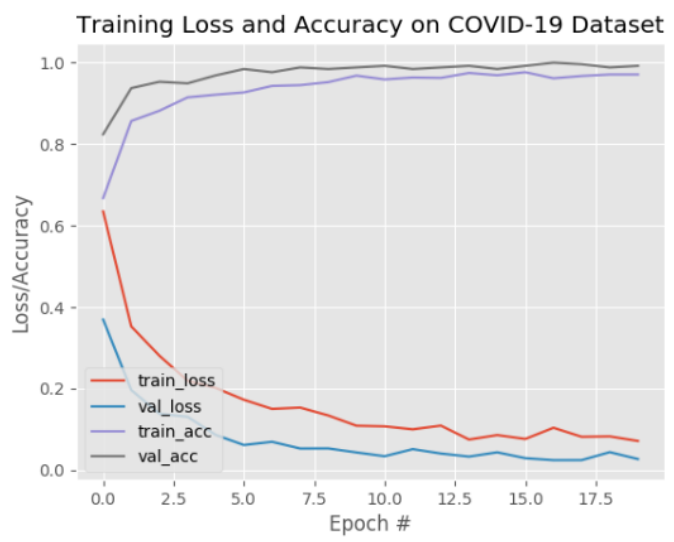

Gambar 8. Training Loss dan Accuracy COVID-19 dataset

Pengujian deteksi dilakukan menggunakan Raspberry Pi yang sudah dipasangkan kamera dan juga PIR sensor seperti ditunjukkan pada gambar 9. Kemudian dengan menampilkan wajah tanpa menggunakan masker dan juga menggunakan masker pada kamera. Dari hasil pengujian terlihat bahwa sistem berjalan dengan baik dengan menampilkan pesan "No Mask Detected" ketika tidak menggunakan masker, dan "Mask Detected" ketika menggunakan masker. Hasil pengujian ditunjukkan pada Gambar 10 dan Gambar 11.

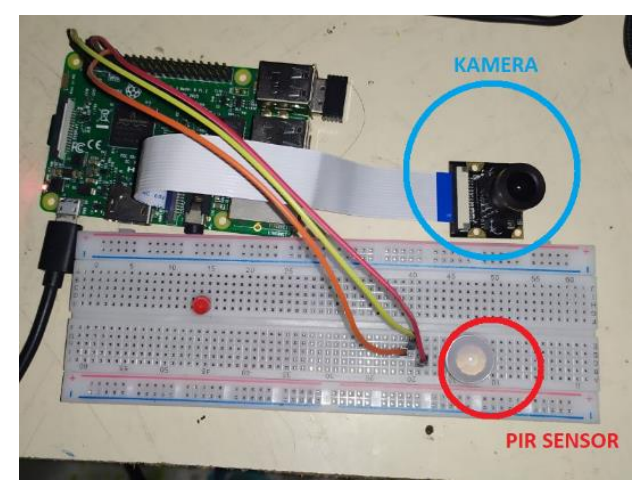

Gambar 9. Raspberry Pi, Kamera dan PIR

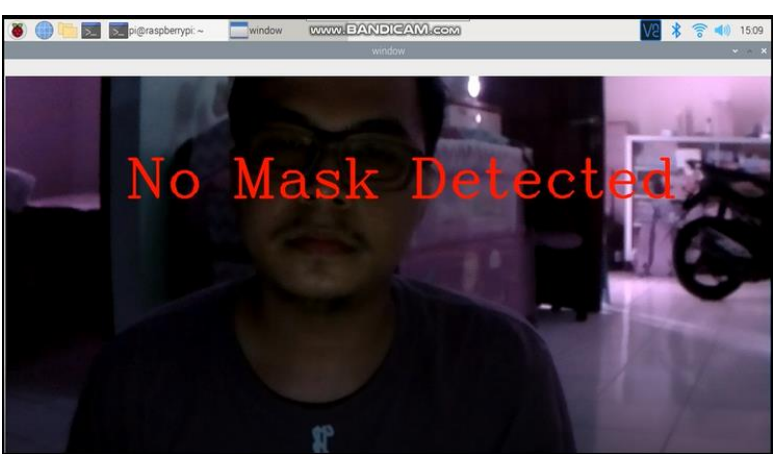

Gambar 10. Masker Tidak Terdeteksi

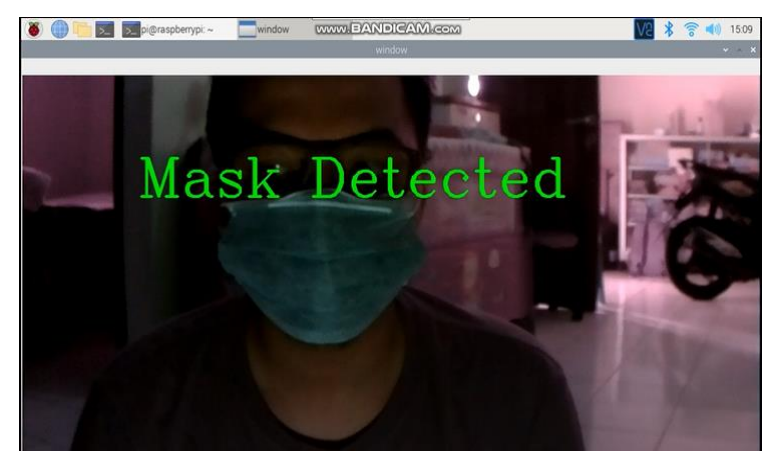

Gambar 11. Masker Terdeteksi

Pengujian notifikasi pada Telegram dilakukan dengan menggunakan BOT Telegram yaitu BotFather[13], yang akan mengirimkan pesan otomatis berupa pesan dan gambar ketika masker terdeteksi. Hasil ini ditunjukkan pada Gambar 12. 


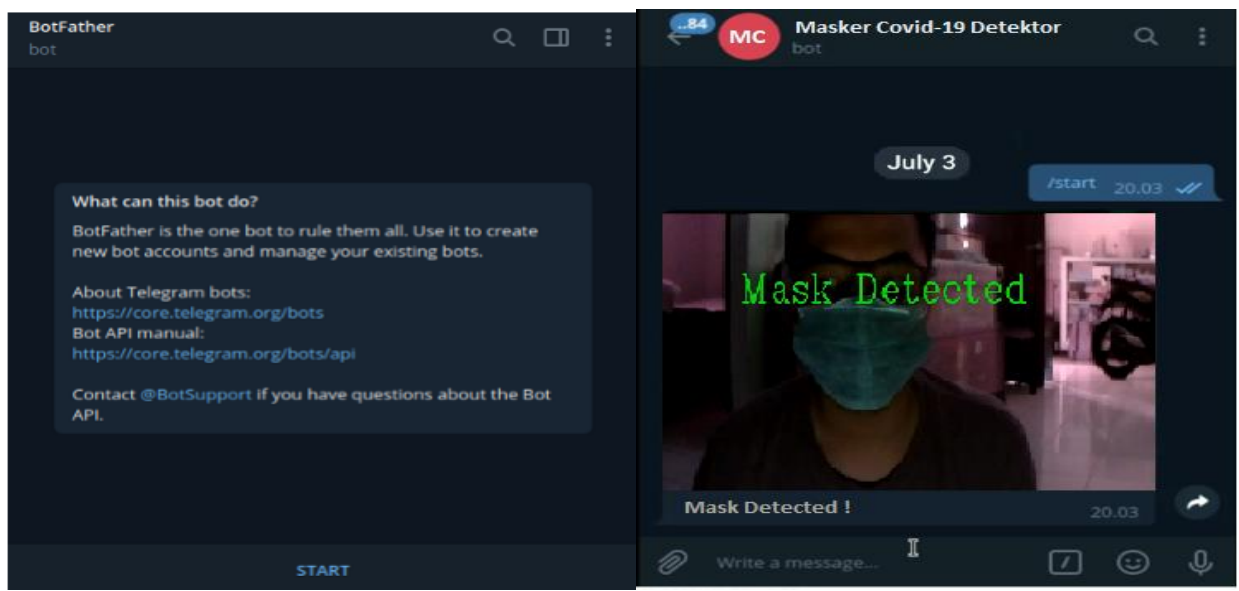

Gambar 12. Notifikasi Telegram Masker Terdeteksi

\section{KESIMPULAN}

Rancang Bangun New Normal COVID-19 Masker Detektor dengan Notifikasi Telegram berbasis Internet Of Things dapat berjalan dengan baik, mampu mendeteksi masker yang digunakan oleh manusia juga dapat mengirimkan notifikasi langsung ke Telegram sebagai pemberitahuan ke petugas keamanan.

Kekurangan Utama dari sistem ini adalah streaming video yang sedikit lambat karena Raspberry Pi memiliki memory yang terbatas, di mana hanya dapat menjalankan streaming video 20-32 fps, sehingga gambar terlihat sedikit tersendat. Solusi terbaik adalah dengan menambahkan modul Accelerator seperti Google Coral,Intel's Neural Compute Stick sebagai processor tambahan yang digunakan untuk implementasi AI.

Kemudian, agar masker wajah terdeteksi dengan baik dibutuhkan kondisi cahaya yang lebih baik, karena jika lokasi pemasangan dilakukan di lokasi yang tidak cukup cahaya, masker detektor tidak cukup baik untuk mendeteksinya.

\section{SARAN}

Untuk penelitian lebih lanjut, Rancang Bangun New Normal COVID-19 Masker Detektor dengan Notifikasi Telegram berbasis Internet Of Things bisa diintegrasikan dengan Akses Kontrol masuk ruangan di mana jika orang menggunakan masker bisa langsung masuk tanpa harus menunggu petugas keamanan membuka pintu ruangan.

Selain itu, untuk memperbaiki masalah streaming video yang sedikit lambat karena kurangnya memory Raspberry Pi, bisa digunakan modul Accelerator seperti Google Coral TPU USB Accelerator[14], Intel's Movidius Neural Compute Stick [15]sebagai processor tambahan yang sangat cocok untuk implementasi AI.

\section{DAFTAR PUSTAKA}

[1] Peraturan Gubernur, "Peraturan Gubernur Provinsi Daerah Khusus Ibukota Jakarta," Corona.Jakarta.Go.Id, vol. 7, pp. 583-606, 2020.

[2] Kementerian Kesehatan, "Kesiapan Kemenkes Dalam Menghadapi Outbreak Novel Coronavirus ( 2019-NCov )," Ditjen Pencegah. Dan Pengendali. Penyakit Kementeri. Kesehat., pp. 1-26, 2020.

[3] R. Novrianda Dasmen, "Implementasi Raspberry Pi 3 Sebagai Wireless Access Point Pada STIPER Sriwigama Palembang," J. Inform. J. Pengemb. IT, vol. 3, no. 3, pp. 387-393, 2018, doi: 10.30591/jpit.v3i3.943.

[4] G. Kutukian and M. Husain, "Raspberry Pi 3 Home Network Monitoring Tool,” 2016. 
[5] W. S. Eka Putra, "Klasifikasi Citra Menggunakan Convolutional Neural Network (CNN) pada Caltech 101," J. Tek. ITS, vol. 5, no. 1, 2016, doi: 10.12962/j23373539.v5i1.15696.

[6] S. R. DEWI, "Deep Learning Object Detection Pada Video," Deep Learn. Object Detect. Pada Video Menggunakan Tensorflow Dan Convolutional Neural Netw., 2018.

[7] P. B., V. M., S. Jadhav, and M. B. Potdar, "Smart Motion Detection System using Raspberry Pi," Int. J. Appl. Inf. Syst., vol. 10, no. 5, pp. 37-40, 2016, doi: 10.5120/ijais2016451506.

[8] M. Jiang, X. Fan, and H. Yan, "RetinaMask: A Face Mask detector," 2020.

[9] K. He, X. Zhang, S. Ren, and J. Sun, "Deep residual learning for image recognition," Proc. IEEE Comput. Soc. Conf. Comput. Vis. Pattern Recognit., vol. 2016-December, pp. 770778, 2016, doi: 10.1109/CVPR.2016.90.

[10]F. Sirait and Y. Yoserizal, "Pemanfaatan Raspberry Pi Sebagai Processor Pada Pendeteksian Dan Pengenalan Pola Wajah," J. Teknol. Elektro, vol. 7, no. 3, pp. 146-150, 2016, doi: 10.22441/jte.v7i3.892.

[11] M. Sandler, A. Howard, M. Zhu, A. Zhmoginov, and L. C. Chen, "MobileNetV2: Inverted Residuals and Linear Bottlenecks," Proc. IEEE Comput. Soc. Conf. Comput. Vis. Pattern Recognit., pp. 4510-4520, 2018, doi: 10.1109/CVPR.2018.00474.

[12]F. Evan, "Penerapan Image Classification Dengan Pre-Trained Model Mobilenet Dalam Client-Side Machine Learning Pen 'Erapan Image Classification Dengan Pre-Trained Model Mobilenet Dalam Client-Side Machine Learning," 2020.

[13] G. Francis, M. Kishorekumar, T. Thilakram, and R. Hariprasath, "Home Automation Chat Bot using IOT ISSN NO : 0042-9945 Home Automation Chat Bot using IOT Page No: 92," no. March, 2020.

[14] M. G. S. Murshed, C. Murphy, D. Hou, N. Khan, G. Ananthanarayanan, and F. Hussain, "Machine Learning at the Network Edge: A Survey," no. February 2020, 2019.

[15] A. Author and A. Address, "Embedded Deep Learning for Face Detection and Emotion Recognition with Intel R Movidius TM Neural Compute Stick," no. Nips, pp. 32-35, 2018. 